\title{
特集 膜の構造制御と機能
}

\section{相転換法による膜構造制御}

\author{
川上浩良
}

東京都立大学大学院工学研究科応用化学専攻 192-0397 東京都八王子市南大沢1-1

\section{Membrane Structure Controlled by Phase Inversion Process}

\author{
Hiroyoshi Kawakami \\ Department of Applied Chemistry, Tokyo Metropolitan University \\ Hachioji, Tokyo 192-0397, Japan
}

The control of 3- dimensions membrane structure is of primary concern in the development of new separation membranes. Here, a new possibility for separation membrane is presented using a phase inversion process. The structure of the asymmetric membrane fabricated by a dry/wet phase inversion process showed an ultrathin skin layer and sponge-like structure characterized by the presence of macrovoids. We have prepared a series of asymmetric membranes with different defect-free skin layer thicknesses from 10 to $5.0 \times 10^{3} \mathrm{~nm}$ by the dry/wet phase inversion. The gas selectivity of the asymmetric membrane increases with a decrease in the surface skin layer thickness, which may be due to the fact that the surface skin layer of the membrane with a thinner thickness forms a more packed structure. On the other hand, porous membranes with nanoscale pore sizes are of interest in areas such as catalysis, sensors, size- and shape-selective separation media, adsorbents, and scaffolds for composite materials synthesis. Those with pore sizes on the order of $1 \mathrm{~nm}$ to $10 \mu \mathrm{m}$ are required. A new possibility for porous membrane is presented using a phase inversion process.

Key words : phase inversion process / asymmetric membrane/fluorinated polyimide/porous membarne/ nanoscale pore

\section{1.はじめに}

透過性・選択性をあわせ持つ分離膜の実現は膜 研究の一つの大きな課題である。これまで多くの 高分子が合成されその透過性や選択性が検討され てきた。しかし，例えば気体分離膜を例にとると， 両者の間にはTrade-offの関係が成り立つため両特 性をともに満たす高分子膜は報告されていない.
従来, このTrade-offの関係を打破するため, 新規 高分子を合成する方法が試みられてきた。しい， トリメチルシリルプロピン以来，際立った透過特 性を持つ高分子はほとんど合成されていないのが 現状である。

一方, 既存の高分子の膜構造を制御し, 透過性 や分離性能を向上させる方法はこれまであまり行 われてこなかった。多孔質膜では孔径が分離性能 


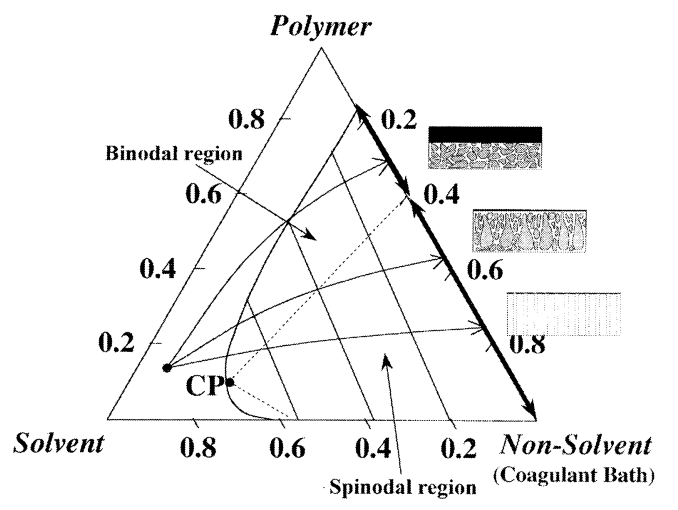

Fig. 1 Ternary phase diagram in solvent/non-solvent/polymer system.

の支配因子となるため, 製膜法に関する検討は行 われている。しかし, 気体分離膜に関しては, 透 過性を高めるための膜の薄膜化は試みられている が，膜構造を積極的に制御し分離性能を向上させ ようという検討はほとんど報告されていない。今 後の高分子膜研究の 1 つのtrendとして, ナノレ ベルで精密に構造制御された高分子膜を設計する ことが求められると考えられる.

本稿では, 高分子気体分離膜で見られる従来の Trade-offの関係を打ち破るため，相分離法を用い た新しい気体分離膜の作製方法を紹介する。高分 子膜の構造を制御する方法は数多くあるが，高分 子のスピノーダル分解を利用した相分離法は, 容 易に膜を作製でき，しかもその条件をコントロー ルすることにより, 表面が完全に緻密な膜構造か ら孔を持つ多孔質膜まで幅広い膜形態を作製でき るため，優れた製膜法といえる．Fig.1には，ス ピノーダル分解と膜構造の関係を示したが，その 分解速度を制御することにより緻密膜から多孔質膜 まで任意の膜形態を作製できる。ここでは我々の研 究成果を中心に，この分野の最新動向を解説する。

\section{2. 相転換法による気体分離膜の作製}

相分離法を用い気体分離膜を作製する試みはこ れまでも幾つか報告されている。例えば， Kestingらはルイス酸ールイス塩基を添加したポリ スルホン溶液を湿式プロセスから作製し非対称膜

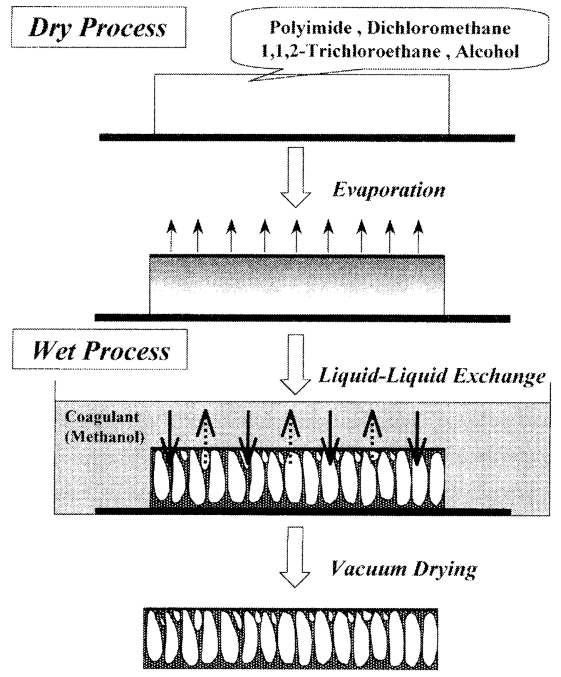

Fig. 2 Fabrication of asymmetric membrane made by dry/wet phase inversion.

を得ている ${ }^{1)}$ ししかし，その膜の表面スキン層に はdefectが存在するため，シリコーンコーティン グ処理を施し気体透過性を検討している。また， Korosらもポリスルホンで乾湿式プロセスにより 超薄膜スキン層を持つ非対称膜の作製に成功して いる ${ }^{2,3}$ ．計算より求めた見かけの表面スキン層 の膜厚は，最も薄い膜で $270 \AA$ を示した。しかし， その非対称膜の気体選択性は膜厚が薄くなるに従 い，緻密膜から算出された理想選択性より低下す る傾向を示した。この気体選択性の低下は，一般 的に見られる薄膜化に伴うdefectの生成が原因で ある。ここで紹介した相分離法により作製した膜 は，膜の薄膜化に伴う透過性の向上を主目的とし ていたため，薄膜作製が可能であったという点を 考慮すると，十分な成果が得られたといえよう。 しかし，気体選択性の面から考えると必ずしも満 足いく結果ではない。

我々の製膜方法も基本原理はFig.1に示した，ス ピノーダル分解を利用した相分離法である4-8). その製膜プロトコールをFig. 2に示す．完全無欠陥 な超薄膜表面スキン相 (膜厚は $100 \AA$ 程度) からな る非対称膜を作製する上での要件は，いかに早く相 分離を誘発しその後迅速にゲル化させるかである.

高分子にはガラス状高分子であるポリイミドを 


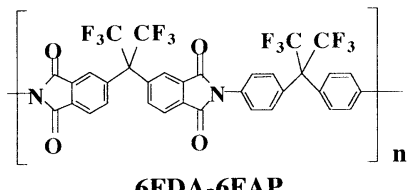

6FDA-6FAP

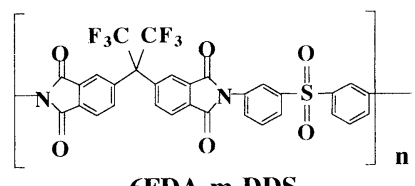

6FDA-m-DDS

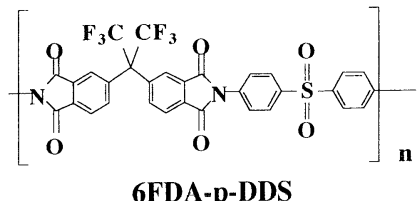

6FDA-p-DDS

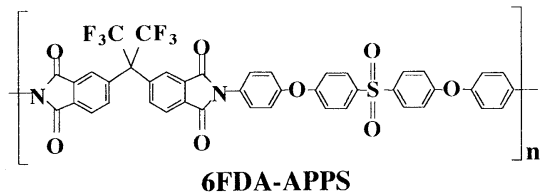

6FDA-APPS

Fig. 3 Structure of fluorinated polyimides

用いた。ガラス状高分子であるポリイミドの気体 透過係数は必ずしも高くない.しかしポリイミド は機械的強靫さに優れているため, 有機溶媒に可 溶なポリイミドを合成しその製膜法を確立するこ とができれば，ポリイミド超薄膜は実用化にも十 分耐えうる強度を持ちえると考えた.さらに,ポリ イミドは分子間で相互作用 (CT作用, $\pi-\pi$ 作用等) を形成するため，薄膜形成時にその相互作用を制 御できれば気体選択性の向上も同時に期待できる.

まず有機溶媒可溶なポリイミドを合成するた め，フッ素基を導入した含フッ素ポリイミドを選 択, さらに温和な条件で重合が可能な化学イミド 化法を用い高純度ポリイミドを合成した。合成し た含フッ素ポリイミドの一例をFig. 3に示す.

次に，乾湿式相転換法による具体的な膜作製条 件は示す (Fig. 1参照). 先ず 3 種類の溶媒（ジク ロロメタン，トリクロロエタン，アルコール）に ポリイミドを溶解させ, ガラス板上に流延する. 一定時間ガラス板上で静置した後, 膜を凝固浴に 浸漬させ15時間後に取りだ真空乾燥を施す。ポ リイミド膜から完全に溶媒を除去することにより

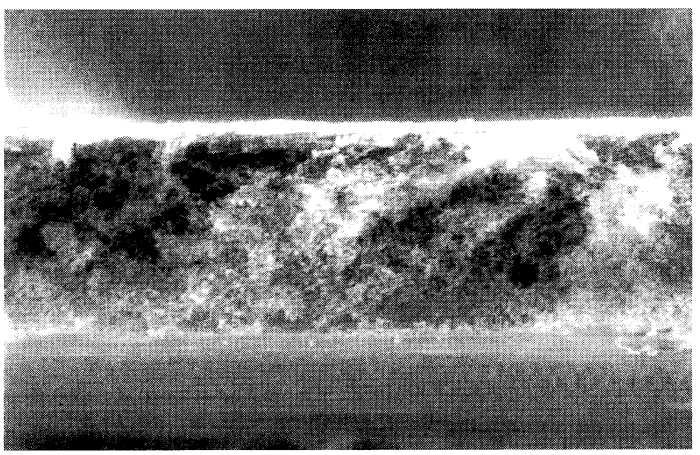

- : $10 \mu \mathrm{m}$

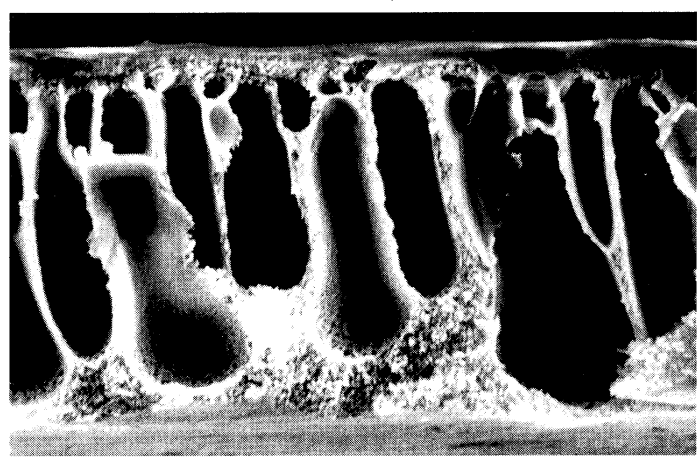

$-: 10 \mu \mathrm{m}$

Fig. 4 Cross-section of asymmetric 6FDA-6FAP membranes. (a) Methanol; (b) Octhanol.

膜の作製は終了となる。相分離に影響を与える因 子としては, ポリイミド溶液濃度, 溶媒組成, ア ルコール，静置時間，凝固浴などがある。つまり， これら多くのパラメータの最適化を行い製膜する 必要がある。この中で, 膜厚や膜構造の支配因子 として貧溶媒であるアルコールの影響は大きい. 例えば，アルコール濃度や種類により膜構造は劇 的に変化する．鎖長の短いアルコールでは多孔質 構造がスポンジ状となるのに対し，鎖長の長いア ルコールでは多孔質構造にfinger voidを含むこと が確認されている (Fig. 4)。これは，アルコール 種による相分離速度の違いが膜構造に反映された 結果である。つまり，湿式プロセスで，アルコー ル種による液一液交換速度に違いが生ずるため, 相分離速度に影響を与え, 全く異なる多孔質構造 が形成されたと考えられる。多孔質の形成メカニ ズムをFig. 5に示した。液一液交換により膜内で形 


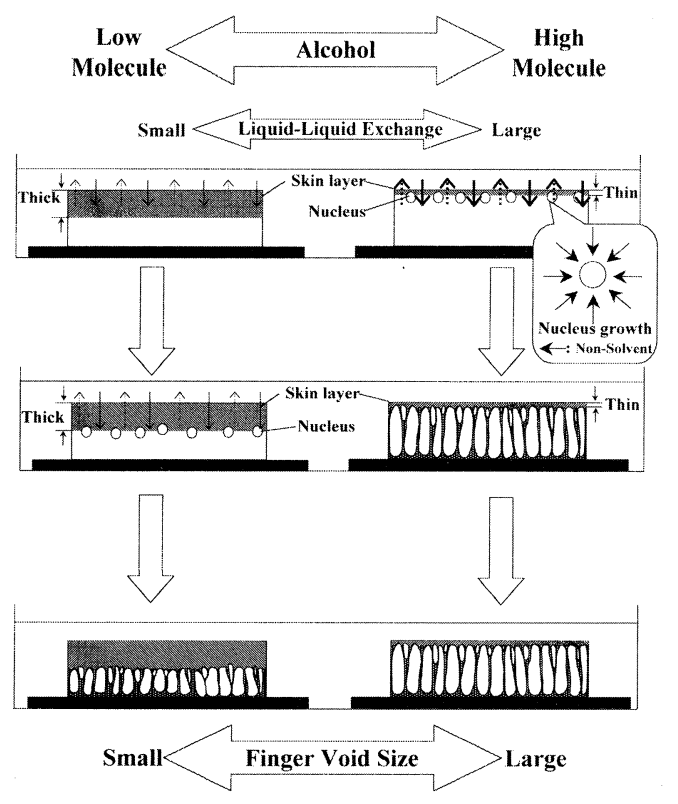

Fig. 5 Nucleus growth mechanism in polymer membrane prepared by dry/wet phase inversion.

成された核が，流入する凝固液（メタノール）量 に依存して成長しfinger voidが形成されたと考察 した.

一方，乾式プロセスの静置時間は膜厚を支配す る重要な因子である（Fig. 6)。乾湿式相転換法を 用いることにより膜厚（表面スキン層）の制御は 極めて容易に行うことができ，静置時間などの条 件を考慮することにより，膜厚を $10 \mathrm{~nm} \sim$ 数 $\mu \mathrm{m}$ の オーダーで自在にコントロールできることが明ら かとなった．含フッ素ポリイミド非対称膜の表面 をAFMで観察すると，表面の平滑性も製膜条件 に著しく依存し, 静置時間の増加とともに凹凸 （ノジュールと呼ばれる）拈よびノジュール幅の 減少が確認された ${ }^{5)}$. 静置時間が短いとスキン層 の膜厚は薄くなるため, 凝固液であるメタノール が迅速かつ多量にポリマー溶媒と交換を行い，表 面上には大きなノジュールが形成される（例えば

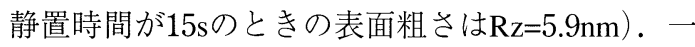
方，静置時間が長いと厚いスキン層が形成される ため，液一液交換は抑制され平滑性（例えば静置 時間が $600 \mathrm{~s}$ のき $\mathrm{Rz}=1.6 \mathrm{~nm}$ ）の高い表面形態が形

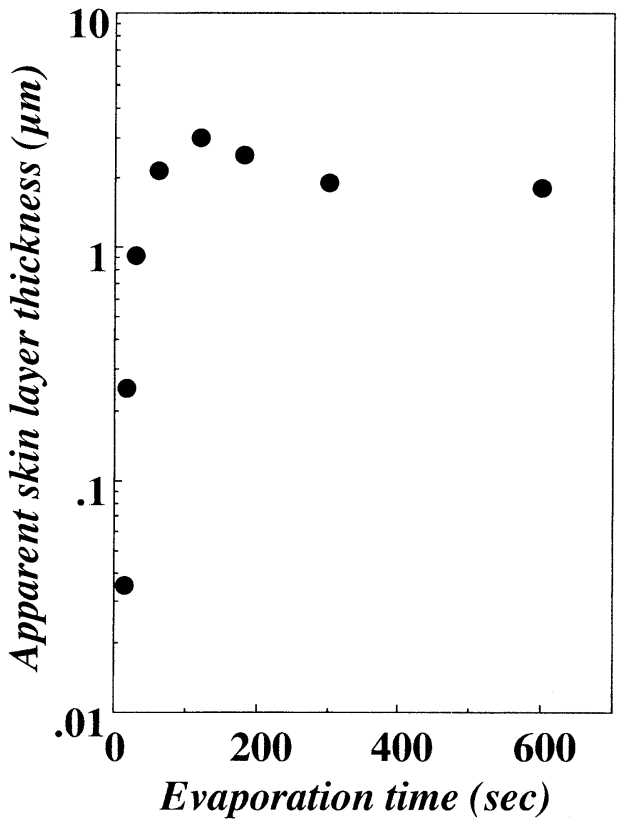

Fig. 6 Evaporation time dependence of apparent skin layer thickness in asymmetric 6FDA-6FAP membranes.

成されることになる，含フッ素ポリイミド非対称 膜の膜表面の形態学的変化にも相分離にともなう 液一液交換が大きく関わっていることがわかる.

\section{3. 相転換法による気体分離膜の作製}

乾湿式相転換法を用い製膜条件を制御すること により，気体の分離活性層となる表面スキン層の 膜厚を10nmまで超薄膜化がすることが可能となっ た。なお，ここで示す膜厚とは，SEMなどから直 接求めたスキン層の厚さではなく, 既知の気体透 過係数と実測した非対称膜の気体透過流量から計 算により求めた見かけの膜厚（L）のことである.

$$
\mathrm{L}=\mathrm{P} / \mathrm{Q}
$$

$\mathrm{P}$ ：ポリイミド緻密膜（膜厚 $50 \mathrm{~nm}$ 程度）の気体透 過係数, Q：ポリイミド非対称膜の気体透過流量 超薄膜スキン層を有する含フッ素ポリイミド非 対称膜では得られる気体透過流量は極めて高く, 例えば， $\mathrm{Q}_{\mathrm{CO}_{2}}>2 \times 10^{3} \mathrm{GPU}, \mathrm{Q}_{\mathrm{O}_{2}}>7 \times 10^{2} \mathrm{GPU}$ $\left(\mathrm{GPU}=10^{-6}\left[\mathrm{~cm}^{2}(\mathrm{STP}) /\left(\mathrm{cm}^{2} \mathrm{~s} \mathrm{cmHg}\right)\right]\right)$ が確認され た. 含フッ素ポリイミド非対称膜のこの気体透過 


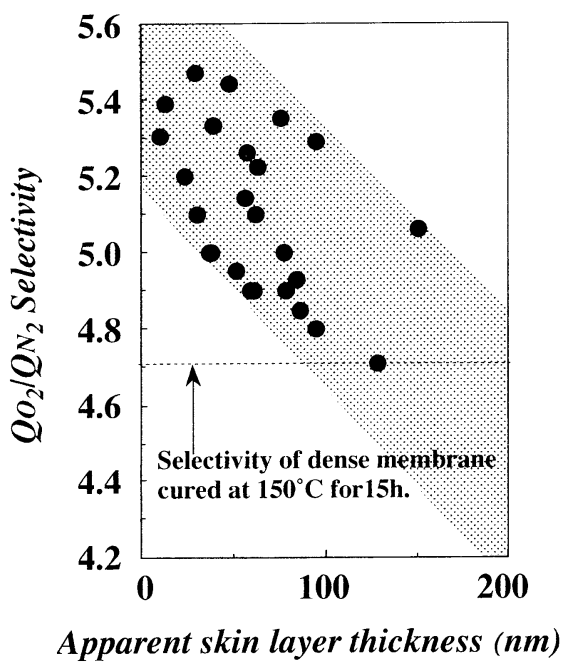

Fig. 7 Gas selectivities of asymmetric 6FDA-6FAP membranes at $35^{\circ} \mathrm{C}$ and $76 \mathrm{cmHg}$.

性は従来の分離膜の透過性を遥かに越えるもので あり,新しい高透過性膜の可能性が示されている.

次に乾湿式相転換法を用い作製した含フッ素ポ リイミド非対称膜の表面スキン層の膜厚と気体選 択性の相関を示す. Fig. 7より, 非対称膜の気体 選択性 $\left(\mathrm{O}_{2} / \mathrm{N}_{2}\right),\left(\mathrm{CO}_{2} / \mathrm{CH}_{4}\right)$ は緻密膜（膜厚 $50 \mathrm{~nm}$ 程度）に比べ増大していることがわかる。 さらに大変興味深いことに, 非対称膜の気体選択 性は表面スキン層の薄膜化にともない一段と向上 する結果となった。これは，薄膜形成過程でポリ イミドがより高次構造をとるためポリイミド間の 分子間相互作用が増大, 密度の増加や秩序構造の 形成が拡散選択性に反映され気体選択性が向上し たためと考えられる。しかもその秩序化は膜厚に 対し傾斜的に形成され, 膜表面に進むほど秩序化 は強調されていると考えられる6).

含フッ素ポリイミド非対称膜中のポリイミド構 造の秩序化は, 気体透過測定, 固体NMR, X 線, 表面蛍光測定などから裏付けられている。例えば, 非対称膜の表面スキン層の薄膜化に伴い，気体透 過の活性化エネルギーは増大し, その傾向は気体 の種類に依存する結果となった ${ }^{6)}$ 。これらは，高 分子構造の秩序化が膜厚に対して傾斜的に形成さ れたことを支持する結果である。含フッ素ポリイ
ミド非対称膜はFig. 7から明らかなように, 膜厚が 薄くなるほど，つまり気体透過性が向上するほど， 気体選択性が増大することがわかった。この非対 称膜は従来不可能とされた，気体透過性と選択性 をともに向上させる “正の相関”を示した例である.

高分子超薄膜で問題となるのは，薄膜を透過す る気体が長期間安定して透過性を維持できるかと いうことである。薄膜の気体透過性の経時的な安 定性を明らかにすることは, 薄膜を分離膜として 実用化する上でも極めて重要な課題である。しか し，これまで完全無欠陥な超薄膜を作製すること が困難であったことと，膜厚を自在にコントロー ルする製膜法が確立されていなかったため，超薄 膜を透過する気体の経時的な安定性を詳細に検討 することは行われてこなかった。

Pinnauらは，超薄膜スキン層（膜厚 $540 \AA$ ）を もつポリスルホン非対称膜が $\mathrm{CO}_{2}$ 高圧力下で容易 に可塑化されることを報告している ${ }^{9)}$. 我々も， 乾湿式相転換法を用いることにより膜厚の異なる 含フッ素ポリイミド非対称膜6FDA-6FAPを作製 し, 膜厚と気体透過安定性の相関を検討した。結 論から述べると, 超薄膜でも高分子量体のポリイ ミドから非対称膜を作製すれば，長期間安定に気 体透過性を維持できることが明らかとなった。 $\mathrm{CO}_{2}$ 高圧力下 $(760 \mathrm{cmHg})$ でも, 高分子量ポリイ ミドを用い作製した超薄膜スキン層を有する非対 称膜（スキン層の膜厚 $500 \AA$ ）では可塑化が抑制 されることが確認された。

また，この製膜法は平膜だけでなく中空糸膜の 作製にも応用可能で，既に我々は含フッ素ポリイ ミド中空系膜の作製にも成功している10). 平膜で の作製条件を用い 3 元溶媒系で乾湿紡系を行うこ とにより，完全無欠陥な薄膜スキン層からなる非 対称構造を有する含フッ素ポリイミド中空糸膜を 作製した。また，中空糸膜では製造時に剪断応力 を受けるため, 表面スキン層でポリイミドの配向 が起こり，より秩序化された高分子構造の形成に より，気体選択性は向上し，非対称膜をも上回っ た。中空糸膜ではさらに高い気体分離性能が期待 できる。 


\section{4. 相転換法による多孔質膜の作製}

一方，湿式法を用いた多孔質膜の作製は，その 形成メカニズムの解明と併せ多くの研究が進めら れている ${ }^{11-12)}$. しかし, 分離機能やファウリング 抑制にその目的が置かれ，孔構造や細孔構造の制 御まで検討した例は少ない.Wangらはポリマー 溶液に貧溶媒を加えることにより，膜表面に cellular surface構造 (六角形に近い多角形構造) をもつ多孔質膜の作製に成功した ${ }^{13}$. 従来，無機 膜ではナノスケールの規則的な細孔構造を持つ多 孔体が多く合成されてきたが，高分子材料で孔の 形までコントロールした膜の報告はほとんどない.

我々も乾湿式相転換法を用い相分離条件を変え ることにより，表面に孔を規則的に形成させるこ とが可能であることを報告している ${ }^{14)}$. 既に乾湿 式相転換法を用いることにより孔径を数 $\mathrm{nm}$ - 数 $十 \mu \mathrm{m}$ の範囲で自由にコントロールでき, 貧溶媒 （アルコール）の添加により膜構造の制御が可能 であることも明らかにしている，孔となる核形成 とその成長を制御できれば，最終的には膜全体の 多孔体構造をコントロールした 3 次元構造体の合 成が可能となり，新しいナノパターニング化膜の 作製に繋がると考えられる。

近年，多孔質膜は溶質の分離機能だけでなく， 各種デバイスとして，また，制御された反応空間 場として関心を集めている。耐熱性や機械強度に 優れたポリイミド材料を用い高い規則性を有する 多孔体をナノレベルで構築できれば，新しいナノ テクノロジー分野を切り拓く有機材料として応用 可能と思われる。

\section{5. おわりに}

本報では，高分子のスピノーダル分解に基づく 相分離法を利用した分離膜の設計について概説し た。今後の高分子膜には, 複数の機能を併せ持つ 機能膜が求められることになろう。新規機能性高 分子の合成が新しい機能膜を設計する上での 1 つ の指針となるが，一方でその機能を膜内でいかに 効率的に発現させるかということも重要になる.
そのためには膜構造全体を 3 次元レベルで精密設 計していく必要がある。今回紹介した乾湿式相転 換法は，簡便でしかも大面積で膜構造を制御でき るため, 一つの有効な製膜法と思われる.

また，紙面の関係で詳細は割愛したが，高度に 規則化された孔径を持つ多孔質膜が合成できれ ば, 従来の分離膜としての応用以外に, バイオチ ップとして，また組織工学で用いられる細胞の足 場としての培養基材として利用でき，その応用は 極めて広範囲に及ぶことになる。特にメンブラン テクノロジー, バイオテクノロジー，ナノテクノロ ジーの融合による作り出される新しいバイオ材料 は, ナノスケールの化学反応システムの構築を可 能とするため, 製造・操作・メンテナンスなどにお いてコストの削減が図れるだけでなく, 廃棄物の 低減など環境負荷の少ないシステムの構築も可能 となる.これら新しいテクノロジーの鍵技術として 3 次元レベルでの膜構造制御が重要と考えられる.

\section{文 献}

1) R. E. Kesting, J. Polym. Sci. Polym. Lett. Ed., 27, 187 (1987).

2) W.J. Koros, G. K. Fleming, J. Membr. Sci., 83, 1 (1993).

3) I. Pinnau, W.J. Koros, J. Appl. Polym. Sci., 43, 1491 (1991).

4) H. Kawakami, M. Mikawa, S. Nagaoka, J. Appl. Polym. Sci., 62, 965 (1996).

5) H. Kawakami, M. Mikawa, S. Nagaoka, J. Membr. Sci., 137, 241 (1997).

6) H. Kawakami, M. Mikawa, S. Nagaoka, Macromolecules, 31, 6636 (1998).

7）川上浩良, 高分子, 47[12], 872 (1998).

8）川上浩良，膜， 24[4], 200 (1999).

10) M. Niwa, H. Kawakami, S. Nagaoka, T. Kanamori, T. Shinbo, J. Membr. Sci., 171, 253 (2000).

11) J.-Y. Lai, F.-C. Lin, T.-T. Wu, D.-M. Wang, J. Membr. Sci., 155, 31 (1999).

12) I. M. Thakore, S. Desal, B. D. Sarwade, S. Devi, J. Appl. Polym. Sci., 71, 1851 (1999).

13) D.-M. Wang, T.-T. Wu, F.-C. Lin, J.-Y. Hou, J.-Y. Lai, J. Membr. Sci., 169, 39 (2000).

14) 川上浩良, 清水秀幸, 長岡昭二, 高分子学会予稿集, 49(4), 831 (2000).

（受付 2001年2月8日 掲載決定 3月10日） 